\title{
Development of skid mounted improved butter churn suitable for small scale production
}

\author{
Adarsh M. Kalla ${ }^{1 *}$, C. SAHU ${ }^{2}$ and A. K. AgraWAL ${ }^{3}$
}

'Department of Dairy Engineering, National Dairy Research Institute, Southern Regional Station, BENGALURU (KARNATAKA) INDIA

${ }^{2}$ Department of Engineering, College of Dairy Science and Food Technology, Chhattisgarh Kamdhenu Vishwavidyalay, RAIPUR (C.G.) INDIA

${ }^{3}$ Department of Dairy Engineering, College of Dairy Science and Food Technology, Chhattisgarh Kamdhenu Vishwavidyalay, RAIPUR (C.G.) INDIA

Email: Adarshkalla002@gmail.com

*Author for Correspondence

Research chronicle : Received : 17.09.2017; Revised : 15.11.2017; Accepted : 30.11 .2017

\section{SUMMARY :}

A survey of traditional butter making in India would reveal that butter production in rural areas is still not technically advanced.To overcome this problem, a skid mounted improved frustum cone shaped insulated butter churn of small size was developed. In the present improved butter churn,the churning time required is reduced by providing internal stirring wing, thus, the process becomes more efficient with reduced labour requirements. With this churn cream from about 100 litres of milk could be processed daily into butter. In India small capacity skid mounted improved butter churn would prove to be economic and efficient.

KEY WORDS : Churning efficiency, Traditional butter making, Butter, Cream, Butter churn

How to cite this paper: Kalla, Adarsh M., Sahu, C. and Agrawal, A.K. (2017). Development of skid mounted improved butter churn suitable for small scale production. Internat. J. Proc. \& Post Harvest Technol., 8 (2) : 139-143. DOI: 10.15740/HAS/IJPPHT/8.2/139-143. 